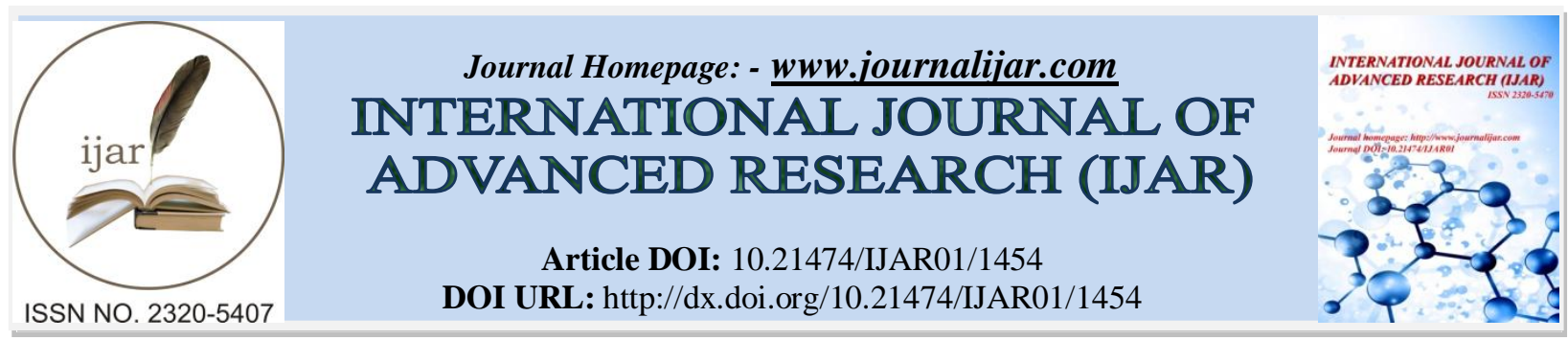

RESEARCH ARTICLE

\title{
THE LONG-TERM CONSEQUENCES OF MANAGING AND SETTLING ETHNIC CONFLICTS THROUGH ETHNIC FEDERALISM: THE CASE OF ETHIOPIA.
}

\author{
Kebede Kassa Tsegaye, PhD.
}

Addis Ababa, Ethiopia.

\section{Manuscript Info}

Manuscript History

Received: 12 July2016

Final Accepted: 19 August 2016

Published: September 2016

Key words:-

ethnic federalism, ethnicity, ethnic diversity, ethnic conflict, Ethiopia.

\begin{abstract}
Ethiopia has more than 80 ethnic groups and over 200 languages and dialects. This diversity has been a source of strength, as demonstrated by the unity of all the ethnic groups in the fight against the Italian invasion in the 1890s and 1930s as well as the Somali incursion in the 1970s. At the same time, ethnic diversity has led the country to protracted wars, for example, between the Tigrian speaking communities in the north (Tigray and Eritrea) and the rest of the country. The war with Eritrea lasted for 30 years, one of the longest in Africa, and ended with the creation of the state of Eritrea in 1991/1993. During the same time the Tigrian rebels toppled over the military regime in Addis Ababa and turned Ethiopia into an ethnofederal state. This paper attempts to examine the literature on the experiences of countries around the globe, including Ethiopia, in ethnic federalism, its rationale and the long-term consequences of this practice, especially for Ethiopia. The paper concludes that while the present ethnic-federal structure has resolved some of the old problems of nationality and ethnic self-governance, studies also show that it has raised more questions than it has answered. Some of the issues that remained unresolved include problems of delineating ethnic boundaries, recurring violent intra/inter-ethnic and regional conflicts, marginalization of people in some federal states that do not belong to the dominant ethnic group, weak capacity and decision-making power of regional federal states to administer justice; and the combined impact of all these on individual liberty which are demonstrated by the continuous narrowing of the political space and the ultimate move toward a dominant one-party 'developmental' state.
\end{abstract}

Copy Right, IJAR, 2016,. All rights reserved.

\section{Introduction:-}

Ethiopia has more than 80 ethnic groups and over 200 languages and dialects. This diversity has been a source of strength, as demonstrated by the unity of all the ethnic groups in the fight against the Italian invasion in the 1890s and 1930s as well as the Somali incursion in the 1970s. At the same time, ethnic diversity has led the country to protracted wars, for example, between the Tigrian speaking communities in the north (Tigray and Eritrea) and the rest of the country. The war with Eritrea lasted for 30 years, one of the longest in Africa, and ended with the creation of the state of Eritrea in 1991/1993. During the same time the Tigrian rebels toppled over the military regime in Addis Ababa and turned Ethiopia into an ethno-federal state. 
A lot has been written about the merits and demerits of ethnic and/or linguistic federalism in Africa, Asia, North America (e.g., Canada) and Europe (e.g., Belgium, Switzerland) (see Osaghae, 2004; He, 2007; Loughlin, 2008). This Paper synthesizes a review of the literature to identify the major successes and failures of ethnic federalism in general and its recent application in Ethiopia in particular. The Paper tries to answer the following questions: has ethnic federalism removed ethnic conflicts in Ethiopia? What are the long-term implications of federalism based on primordial ethno-linguistic ties?

The central argument of this paper is that in the short-run ethnic federalism may be seen as a remedy to problems caused by ethnic tensions and conflicts owing to scarce resources, imbalance of power, exclusion and actual or perceived existential threats. In the long-run, however, ethnic federalism will tend to amplify differences, increase ethnic cleavages, and persistent demand for greater autonomy by some and the desire to maintain the status quo by others (Bednar, et al, 1999; Selassie, 2003; McHenry, Jr, 1997). Throughout the paper, historical experiences of countries in different parts of the world are used to support the argument.

The section that follows provides an overview of the literature on ethnic/linguistic federalism; this is followed by a discussion on the experience of Ethiopia since the country adopted a federal structure based, mainly, on ethnic considerations, as well as the logical contradictions present in this approach. The fourth section presents some examples of recurring ethnic conflicts in Ethiopia since the 1990s; and the final section will offer concluding remarks with emphasis on the long-term consequences of ethnic federalism in the country.

\section{Review of the Literature:-}

In multiethnic and multicultural societies, ethnic conflicts are not only recurrent, but often protracted and highly destructive (Newman, 1991). "Ethnic conflicts are as old as mankind" (Crocker, 1999). Using cases from the Balkans after the Cold War, Crocker identified three types of ethnic conflicts: 'preventive', 'deterrent' and 'punitive'. As there are diverse causes and expressions of ethnic conflicts, their solutions, too, are diverse and complex. In some contexts, denying or suppressing differences and fostering unity may work, whereas in others, recognizing diversity and granting a degree of political, economic and administrative autonomy, including ethnic federalism, could be considered as a remedy. "Ethnic federation is used specifically in the context and strategy of resolving an ethnic conflict on a permanent basis" (Tegenu, nd). Ethnic or linguistic-based federalism is not uncommon even in the most advanced democratic countries, like Belgium (d'Alcantara, 2002). The Belgian system of ethnic federalism is an important example of recurring ethnic conflicts even in a prosperous and mature democracy in the capital of the European Union. As d'Alcantara observed “... conflicts between the Flemish-and French-speaking communities are intensified by a lack of contact with a national majority...Cultural autonomy, expressed in two different languages, generates progressively diverging opinions." The Belgian federation is often threatened by "separatist" elements who wish to create separate states along the ethnic/linguistic lines. This experience is very important and illustrates the existing tensions in apparently autonomous federal states designed to foster integration and "unity in diversity", a phrase often used by politicians and scholars alike in pluralistic societies.

Moreover, the experiences of the disintegration of formerly federal states such as the Federal State of Soviet Socialist Republics, the Federal Republics of Yugoslavia and Czechoslovakia suggest that ethnic federalism, sooner or later, will lead to more and more autonomy and break-up of the parent state. Ethnic conflicts leading to disintegration were extremely intense notably in central and eastern Europe, parts of the Russian Federation and the Caucasus regions (Bednar, et al, 1999; Illes, 2002; Giinliik, 1994 Vujacic, 2002).

In Africa, where ethnic and linguistic diversities are considerably high, there have been efforts to implement the project of ethnic federalism as in the case of Nigeria, South Africa, and Ethiopia, (Selassie, 2003; Bednar, et al, 1999). With regard to Nigeria, ethnic federalism has both resolved and complicated ethnic relations. A series of constitutional changes have emphasized the need for recognizing ethnic differences and for creating a politicaleconomic space to accommodate this diversity with the view to maintaining the country's unity (Ayoade, 1986). However, as Jinadu (2002) noted, “... the centrifugal pull of the political mobilization of ethnicity is a fundamental problem, raised by the rational calculation of the cost of federalism by the covenantal parties". Consequently, ethnic federalism in Nigeria, as in many developing countries, is often associated with actual or perceived elite political and economic opportunities which result in intense struggle for access to public employment, this being the major and even the sole source of survival and prosperity (Ayoade, 1986). After independence, India adopted a mixture of regionalism and ethnic or linguistic federalism in "... ethnically distinct regions where the territorial accommodation 
of distinct groups of people is of paramount importance" (Bhattacharyya, 2005). The practice of creating federal structures based on primordial ties: kinship, language and related affinities has given rise to "... the upsurge of ethnic identities, which are demanding more autonomous spaces for themselves, with some of them demanding statehood within the federal set-up" (Bhattacharyya, 2005).

As the foregoing paragraphs suggest, a handful of multi-ethnic and pluralistic countries adopted ethnic-based federalism as a solution to ethnic conflicts in their respective territories. Their experiences show that some of the federal arrangements disintegrated while others still struggle to preserve their unity. In this connection, it is essential to raise a couple of interrelated questions. First, why do federal states, especially those in Central and Eastern European Countries disintegrate? Second, what is the implication of ethnic federalism (which aims at protecting or promoting group rights) on individual rights and the democratic space? The following section will deal with these and other questions forwarded in the introductory section.

\section{Ethnic Federalism in Ethiopia and Group versus Individual Rights:-}

The history of federalism in Ethiopia dates back to the 1950s when an arrangement was made between Ethiopia and Eritrea after the latter's independence from Italian rule in 1941 and British trusteeship in 1952 in line with UN resolution 390 (v). However, this association collapsed when, in 1962, Emperor Hailesilassie annexed Eritrea into Ethiopia as one of the provinces (Negash, 1997; Metaferia, 2001). The re-incorporation of Eritrea into the unitary structure resulted in discontent and armed resistance, between the 1960s and 1990s, fought along ethnic lines. Eritrea's struggle for independence also set an example for the neighboring province of Tigray which fought a secessionist war to separate from Ethiopia.

The peoples of Tigray and Eritrea share similar ethnic, linguistic, cultural and ecological features. The Tigrian separatist movement began in earnest in 1974, following the Ethiopian Revolution in 1973. Despite some basic differences between them, the Eritrean and Tigrian 'liberation fronts' ${ }^{1}$ collaborated in the fight against the central military regime; and when it was overthrown in 1991, Eritrea declared independence (officially confirmed in 1993). The Tigrian rebels formed a coalition of ethnic-based liberation fronts, controlled Addis, Ababa and established a Transitional Government which adopted a Constitution in 1994/5 that provided for an ethnic-based federal structure.

Ethiopia is not the only country that has created a federal system largely on the basis of primordial - ethnicity, language and cultural - attributes. However, while many of the countries that adopt ethnic federalism systematically avoid provisions for secession and self-determination, the Ethiopian Constitution explicitly recognizes these rights. Article 39 of that Constitution provides that "Every Nation, Nationality and People in Ethiopia has an unconditional right to self-determination, including the right to secession." This provision has been put to practice even before it was adopted as the post-1991 Ethiopian regional administration was crafted along ethnic or nationality lines. Although Ethiopia is home to more than 80 ethnic groups, nations, nationalities and peoples, the country is organized into nine (9) administrative regions, each representing the ethnic group with numeric majority in the region. These are Afar, Amhara, Benishangul Gumuz; Gambella, Harari, Oromia, SNPP ${ }^{2}$, Somali, and Tigray national regional states.

The architects of the Constitution and proponents of ethnic federalism argue that this is the right approach to settle and manage ethnic conflicts, eliminate inequality and remove ethnic domination (Gebru, 2011; Habisso, 2010). As Regassa (2004) puts it "The interest in federalism among the constitution makers of Ethiopia was a reaction to and a result, at a time, of a long history of centralist tendency that was pursued stringently ..." Moreover, "Certain Western academics considered 'ethnic federalism' as innovative, 'giving room for thinking differently about ethnicity in the political evolution in Africa"' (Aalen, 2002). The justification for instituting ethnic federalism is located in decentralization of administration, devolution of power from the center to the constituent elements or regions, and equitable distribution of fiscal and other resources among the federated states presumably on demographic and historical considerations. Advocates of the system refer to the fact that since the adoption of ethnic

\footnotetext{
${ }^{1}$ Different liberation fronts appeared and disappeared due to internal conflicts as well as infiltration by the central government army. Moreover, the Tigrian separatists changed their mind in 1991 when they realized that they were overthrowing the central government and hence able to rule the country rather than to materialize their own region's separation.

2 Southern Nations, Nationalities and Peoples (SNNP). This ethnic-based regional state alone contains over 50 ethnic groups lumped together due to administrative, economic and political inconveniences.
} 
federalism in the early 1990s, the country has not experienced major ethnic conflicts; hence the effectiveness of ethnic federalism to address ethnic diversities.

However, critics of ethnic federalism vehemently argue that the practice will lead to increased conflict and disintegration in the long-run. They also cite evidence of frequent skirmishes between the various ethnic groups that are not satisfied with the present arrangement either because it does not bring them economic and political equity or the system empowers some while it deprives others from gaining autonomy though the Constitution clearly provides for it. A recent study by Gebre-Egziabher (2007) reported that “... since the current ruling party, the Ethiopian People's Revolutionary Democratic Front (EPRDF) took power in May 1991, there have been a number of violent ethnic conflicts widespread throughout the country." Among the major causes identified by the author include:

- Ethno-Centric Federalism and Ethno-Centric Politics: ethnic based regional boundaries and non-clarity resulted in the separation of ethnic groups from their traditional resource bases;

- Using ethnicity for political mobilization (Politicisation of Ethnicity): ethnicity becomes the most efficient base for political mobilization, and it gives enough ground for new local elites to compete for power on the basis of ethnicity;

- Dissatisfactions that exist in the country as a result of absence of public accountability and non-observance of the rule of law by government officials result in grievances that eventually lead to conflict situations.

Another study by Adegehe (2009) stated that contrary to the architects' expectation that Federalism would resolve or dry ethnic conflicts from the source, “... ethnic conflicts are still critical challenges in the country”. Adegehe pinpointed five categories of violent conflicts that complicated the implementation of the project of ethnicfederation. These conflicts include: (i) federal structure and identity conflicts; (ii) intra-federal boundary conflicts; (iii) intra-regional conflicts over federal resources; (iv) conflicts between titular and non-titular groups ${ }^{3}$; and (v) conflict between the government and secessionist movements. Based on the foregoing, the author concluded that:

- $\quad$ "Ethnic federalism prevents the development of a country-wide overarching citizenship;

- Restructuring multiethnic states into ethnic federations tends to generate intra-federal (violent) conflicts.

- A constitutional guarantee for secession prevents the development of the political art of compromise and encourages separatist nationalism.

The above conclusion echoes the admonition by other scholars such as Stepan (1999) who cautioned those who place too much emphasis on "... federal system to reduce ethnic, religious, or linguistic tensions, [since] they could do so only at the risk of severely constraining majority rule" (Stepan, 1999).

\section{Ethnic Federalism, the State of Ethiopian Democracy and the Uncertain Future:-}

Some of the critiques on ethnic federalism come from those which see a causal relationship between promoting group rights at the expense of individual rights. Though the two do not conflict, these sources say, group rights are too general, too diffuse and hard to substantiate. It is often argued that the assertion of one group's right could lead to the suppression of the rights of others, especially those considered 'beneficiaries' of previous systems. In the case of Ethiopia, critics of the present system argue that ethnic federalism was introduced to divide and rule, to weaken opposition from the previously dominant groups, and most importantly stifle liberal democracy which gives primacy to individual rights before or parallel to group rights.

Since 1991, the Ethiopian political space is dominated by the party which overthrew the military regime. After the first four years of transition, 1991 to 1994, Ethiopia held its first regional and parliamentary elections in 1995 (Aalen, 2002) which confirmed the ruling Party of the transition period winning 471 of the 547 seats. During the first few years of the transition period the country seemed to usher in a new era of a democratic beginning, at least seen from the outside, though some contend that this was a very spurious judgment for those who knew what was going on internally: systematic exclusion of genuine opposition parties, massive retrenchment of employees in the public sector, suppression of popular dissent, and spreading or regenerating the propaganda of ethnic hatred. These practices, combined with the explicit compartmentalization of the population into ethnic enclaves, critics argue,

\footnotetext{
${ }^{3}$ The author further elaborated that "those who live in their designated ethnic homelands became titular, whereas those for different reasons find themselves out of their designated ethnic homelands became non-titular".
} 
instilled fear and suspicions among people in both the rural and urban areas, gave rise to opportunists, middle-ofthe-road revolutionaries, and power-mongers. "In this respect, ethnic self-determination up to secession, multi-party democracy, free and fair elections and freedom of speech and association, promised by the federal Constitution, remain largely ignored" (Adegehe, 2009).

In the second national election of 2000, again the ruling party won the majority (481 of the 547) seats. The remaining 66 seats went to opposition parties. This was regarded as a slight improvement compared to the previous elections. The democratic process seemed to have matured during the third national election in 2005 where, for the first time in the country's history, opposition parties gained access to the media, political debates and rallies were encouraged and civil societies actively mobilized the electorate. The remarkably huge voter turnout on Election Day on 15 May 2005 surprised the world and led to the conclusion that Africa finally was coming of age to usher in a period of maturing liberal democracy with a growing confidence in the ballot box to change regimes. On election night, however, the ruling party, predicting an impending defeat, especially when it realized that all the 24 seats in Addis Ababa went to the opposition, declared that it had won the election and banned public demonstrations of any sort for a month (CCOM, 2005; Lyons, 2005). The European Union's Election Observation Mission concluded that "Overall, therefore, the Elections fell short of international principles for genuine democratic elections" (EU EOM, 2005). Similarly, the "Carter Center concludes that the 2005 electoral process did not fulfill Ethiopia's obligations to ensure the exercise of political rights and freedoms necessary for genuinely democratic elections" (The Carter Center, 2009:3).

The EU Election Observation Mission made a similar conclusion about the 2010 parliamentary elections in which the same ruling party won $99.6 \%$ of the seats. The Final Report of the EU Election Observation Mission (EU EOM 2010) stated that "...the electoral process fell short of international commitments for elections, notably regarding the transparency of the process and the lack of a level playing field for all contesting parties. Insufficient efforts were taken to ensure a more equitable and representative electoral process." Obviously, the ruling party vehemently denied or rejected these 'accusations' and continued to form the government after each election.

Consequently, opposition parties and academics with critical reflections argue that, like most African countries, Ethiopia is graduating into a dominant party politics surrounded by satellite ethnic-based parties at both federal and regional levels which often take their ethnic name for party names. Critics continue to voice concerns that under such circumstances democracy take a very precarious and dangerous course. Most opposition parties often complain that they are being extremely weakened due to government 'repression' and continually cry foul about the 'increasingly narrowing political space'. International human rights institutions and the media as well as the US Department of State share most of their complaints. For example, Tristan McConnell of the Global Mail reported on 23 May 2011 that "Freedom House this year ranked Ethiopia as 'not free' for the first time". Although such reports are controversial and automatically rejected by the government, they suggest an unhealthy political development with a potential to be exploited, sooner or letter, by discontented parties and groups. The shrinking and gradual disappearance of the democratic space with longevity of certain individuals and their dominant party in power for decades mean a pent-up frustration and despondency among individuals and groups and then a search for the right time to bubble and burst as in the case of the Arab-Springs in North Africa and the Middle East. This will have grave consequences in multi-ethnic societies like Ethiopia and calls for a careful attention and reconsideration taking the realities on the ground into account.

\section{Conclusion:-}

This paper has attempted to examine the literature on the experiences of countries around the globe, including Ethiopia, in ethnic federalism, its rationale and the long-term consequences of this practice, especially for Ethiopia, a country with more than 80 ethnic groups. As noted earlier, Ethiopia adopted ethnic federalism as a remedy for recurrent conflicts triggered by exclusion, domination of the majority of ethnic communities by a handful few, and the resulting inequality in terms of access to resources as well as justice. The experimentation with ethnic federalism, supported by a constitutional provision up to secession, came as a result of a thirty-year war with Eritrea (which broke away in 1991) and a seventeen-year secessionist struggle by the Tigray People Liberation Front (TPLF). The latter managed to put together representatives of some ethnic groups to form a multi-ethnic party and took control of Addis Ababa.

While the present ethnic-federal structure has resolved some of the old problems of nationality and ethnic selfgovernance, several studies show that it has raised more questions than it has answered. Some of the issues that 
remained unresolved include problems of delineating ethnic boundaries, recurrent violent intra/inter-ethnic and regional conflicts, marginalization of people in some federal states that do not belong to the dominant ethnic group, weak capacity and decision-making power of regional federal states to administer justice; and the combined impact of all these on individual liberty - freedom of expression, movement, the right to acquire property anywhere in the country, the right to residence, access and use of the media, etc.

The experience of other multiethnic societies that have emphasized on group rights in the form of ethnic federalism at the expense of individual rights has shown that in the long-run they tend to crack and collapse when the strong hand that held them together weakens. As the limited studies consulted indicate, Ethiopia seems to be in exactly the same situation. In the first place, ethnic conflicts are pervasive even in the present time. A few weeks before the drafting of this paper, the Federal Policy reported that eight ethnic conflicts occurred in the country between October 2010 and April 2011. As the democratic process gets stalled and popular discontent grows, conflicts of interest between the ruling party and the rest of the population may very likely run along ethnic fault-lines. In this regard, the long-term consequences of ethnic federalism could be pronounced differences, destructive clashes and perhaps further breakup of the country.

The author wishes to conclude this paper with a fitting observation by Martin Lewis (2010), historical geographer at Stanford University, in an article titled Ethiopia's Failed Ethnic Federalism which reads:

Ethiopia's ethnic reorganization generated considerable enthusiasm in the international development community at first. It did not last long. By the early 2000s, complaints of continued Tigrayan domination mounted, especially in the Oromo region. Secession movements took root; today the Oromo Independence Movement, the Oromo Liberation Front, the Islamic Front for the Liberation of Oromia, and the Conference of Oromiya Peoples Liberation Front are all classified as actively seeking to split the state. One can add here the Ogden National Liberation Front and other lesser ethnic-based conflicts that are challenging the federal arrangement. In this regard, the subject requires further and deeper empirical studies to generate policy recommendations for improvement.

The future of the country depends on making flexible and timely decisions by all concerned to reduce inter-ethnic tensions and unforeseen consequences of short-term gains at the expense of generations of Ethiopians who are bound together by centuries of historical, sociocultural, political and economic ties.

\section{References:-}

1. Aalen, L., 2002. "Ethnic Federalism in a Dominant Party State: The Ethiopian, Experience 1991-2000” Report R http://www.cmi.no

2. Ayoade, J. A. A., 1986. "Ethnic Management in the 1979 Nigerian Constitution" Publius: The Journal of Federalism 16 (Spring 1986)

3. Bhattacharyya, H., 2005. "Federalism and Regionalism in India Institutional Strategies and Political Accommodation of Identity Heidelberg Papers in South Asian and Comparative Politics South Asia Institute Department of Political Science University of Heidelberg, Working Paper No. 27, South Asia Institute, Department of Political Science, University of Heidelberg http://archiv.ub.uni-heidelberg.de

4. Bednar, J., William N. E. Jr., John F., 1999. A Political Theory of Federalism,

5. Carter Center, the, 2005. Ethiopia National Elections, The Carter Center, Observation Mission, Final Report http://www.andinet.org

6. Crocker, Chester A. "How To Think About Ethnic Conflict" Foreign Policy Research Institute, Volume 7, Number (10 September 1999)

http://www.fpri.org/fpriwire/0710.199909.crocker.howtothinkaboutethnicconflict.html

7. d'Alcantara, G., 2002. Federalism and Decentralization: Perspectives for the Transformation process in Eastern and Central Europe/ Jurgen Rose and Johannes Ch. Traut (editors) Hamburg, LIT.

8. European Union Election Observation Mission (EOM), n.d. Ethiopia 2005, Final Report on the Legislative Elections, http://eeas.europa.eu/eueom/pdf/missions/finalreport-ethiopia-2005.pdf

9. European Union Election Observation Mission to Ethiopia, 2010. Final Report on the House of People's Representatives and State Council Elections, http://www.eueom.eu

10. Gebre-Egziabher, S., 2007. "What Role Should Civil Society Organisations Play To Address Ethnic Conflicts In Ethiopia Paper To Be Presented At The Fourth International Conference on Ethiopian Development Studies $\left(4^{\text {th }}\right.$ ICEDS $)$ on The Challenges And Opportunities For Peace \& Development In Ethiopia \& Northeast Africa, 
(August 2-4, 2007), 2000 Schneider Hall, Haworth College of Business, Western Michigan University, Kalamazoo, USA; http://homepages.wmich.edu

11. Gebru, S. M., 2011. "Did Ethnic Federalism Save Ethiopia?" (February 16, 2011) http://nazret.com/blog/index.php/2011/02/16/did-ethnic-federalism-save-ethiopia?blog=15

12. Getachew, Metaferia, "Eritrea and Ethiopia: The Federal Experience" Journal of Third World Studies / Fall 2001 (this and the preceding article are the same, but bear names of different authors http://findarticles.com

13. Giinliik, N. C. The Yugoslavian Puzzle: Which Nationalism, Whose War, and Other Unsettling Questions Refuge, Vol. 14, No. 3 (June-July 1994)

14. Habisso, T., n.d. "Ethiopia: Incorporating Right of Secession as Tool to Protect Territorial Integrity http://www.ethiopian-news.com/ethiopia-right-of-secession-as-tool-to-protect-territorial-integrity/ (An op-ed published by Ethiopian news but not signed by the authors);

15. He, B., 2006. "Pledging Allegiance: The Federal Solution to Ethnic Conflicts" Georgetown Journal of International Affairs (Summer/Fall 2006) http://www.chinesedemocratization.com.

16. Jinadu, L., 2002. Adele. Ethnic Conflict \& Federalism in Nigeria: Discussion Papers on Development Policy, Center for Development Research, Bonn University, Number 49, Bonn, (September 2002).

17. Lyons, T., 2005. "Ethiopia: Implications of the May 2005 Elections for Future Democratization Programs," IFES (August 2005) http://www.ifes.org

18. Loughlin, J., 2008. Federalism, regionalism and local government: Comparative perspectives on transforming the nation-state, European Consortium for Political Research. 1680-4333/08 www.palgrave-journals.com/eps/

19. Lewis, M.W., 2010. "Ethiopia's Failed Ethnic Federalism," GeoCurrents Map Illustrated Analyses of Current Events and Geographical Issues 23 March 2010 http://geocurrents.info

20. McConnell, Tristan Ethiopia's human rights record scrutinized, May 23, 2011 06:20

21. McHenry, D. E., Jr. 1997. "Federalism in Africa: Is it a Solution to, or a Cause of, Ethnic Problems?" Presented at the Annual Meeting of the African Studies Association in Columbus, Ohio, (November 1997).

22. Newman, S., 1991, “Does Modernization Breed Ethnic Political Conflict?” World Politics 43 (April I 991), 45 I-78.

23. Osaghae, E. E. 2004. "Federalism and the Management of Diversity in Africa" Identity, Culture and Politics, Vol 5, Nos.1 \& 2, 2004, pp.162-178 http://www.codesria.org/IMG/pdf/eghosa.pdf

24. Regfassa, T., 2004. State Constitutions and Federalism in Ethiopia: A Preliminary Observation (A Summary for the Bellagio Conference, (March 22-24, 2004) http://camlaw.rutgers.edu

25. Selassie, Alemante G., "Ethnic Federalism: Its Promise and Pitfalls for Africa" (2003). Faculty Publications. Paper 88. ttp://scholarship.law.wm.edu/facpubs/88

26. Stepan, A. C., 1999. "Federalism and Democracy: Beyond the U.S. Model" Journal of Democracy - Volume 10, Number 4, (October 1999)

27. Tegenu, $\mathrm{T}$ (nd) The Model and Making of Ethnic Federalism: Problems for Consideration

28. Tekeste, N., 1997. "Eritrea and Ethiopia: The Federal Experience. New Brunswick, NJ: Transaction Publishers, http://findarticles.com

29. Vujacic, I., 2002. "The Challenges of Ethnic Federalism: Experiences and Lessons of the Former Yugoslavia", Federalism and decentralization: perspectives for the transformation process in Eastern and Central Europe (Edited by Jürgen Rose, Johannes Ch Traut, George C. Marshall European Center for Security Studies) http://books.google.com/books 